\title{
Prague's Water Supply Station in Podolí - a Solution for the Problems of Clean Water in the 1930s
}

\author{
K. Drnek
}

\begin{abstract}
In the 1920s Prague was seeking a solution to the problem of supplying its inhabitants with drinkable water. The water plant in Káraný was not able to provide enough water, and the bold plan to bring water from a reservoir and to provide a dual system of potable and non-potable water faced an uncertain future.

In order to stave off the crisis and make time to complete its plans, the city council decided to construct a new water supply plant inside the city next to the Vltava river in the city district of Podolí.
\end{abstract}

Keywords: Káraný, Ing. Jaroslav Vancl, Podolí, Puech-Chabal, filtration, large mesh filters, prefilters, fine filters, Ing. Antonín Engel.

\section{Introduction to the problem}

In the 1920s Prague was faced with a crucial problem - how to provide drinkable water for the inhabitants of the city.

Although there was a new system based on the newly constructed water plant in Káraný, Prague needed more water than this new source was able to provide.

The water plant was modernized and expanded but the amount of water that could be drawn was inadequate. New ideas about new resources were put forward, but nothing changed until the end of the 1920 s, when the new water plant was built next to the Vltava river in Podolí.

\section{Prague's water supply system}

In 1913, just before the demise of the AustroHungarian monarchy, Prague finally completed the long proclaimed project of building of a new water supply system that was able to transport clean water to the biggest city in the Czech lands. The project was completed just in time. The first world war was imminent, and without this source of clean water the citizens of Prague would have suffered more health problems than they did.

However, shortly after the first world war ended, problems of water supply again came into the foreground. Prague, the capital city of the newly established republic, was enlarged and combined with its suburbs. The now increased number of inhabitants were in urgent need of clean water. The newly constructed water supply plant was suddenly inade- quate, and the city authorities began to look for a solution.

The system that was supplying Prague with clean water after the first world war was based on four sources, which supplied water of varying quality. The main source was the new water plant in Káraný, which delivered water only to the inner city and the inner suburbs. The second biggest water source was infiltrated water from the Vltava river (the infiltration was mixed with water from Káraný). The water plant was located in Bráník (this water plant was founded in 1876). Water from this source was delivered into just two other city districts. Both of these sources were capable of supplying water suitable for drinking.

The third and fourth sources were both from the Vltava. The river provided water for the factories around the city (many of them had their own water plants) and for the water wells that were located throughout the city. Both of these water sources supplied water that was not suitable for drinking.

The main water source was still Káraný, and the city fathers were working on providing enough water from Káraný to supply the whole city. Despite the modernization works, Ing. Jaroslav Vancl, head of the water department in the Technical Office of the city, set up a project for future extension of the water supplies.

\subsection{Water plant in Káraný}

The water plant was first set up in 1905, and was finally completed in 1913. The plant was planned only for the inhabitants of inner Prague and the surrounding suburbs. It was planned to supply only 120 1 per day and per person. By the end of the war, the amount of water that was supplied had risen to $170 \mathrm{l}$ 
per day and per person, but the dilapidated pipelines also led to considerable losses.

During the 1920s, the capacity of the plant was enlarged to its final amount of $80000 \mathrm{~m}^{3}$ per day. However, this was not enough, because the numbers of people connected to the water plant kept growing, as did the amount of water used per person to $200 \mathrm{l}$ per day.

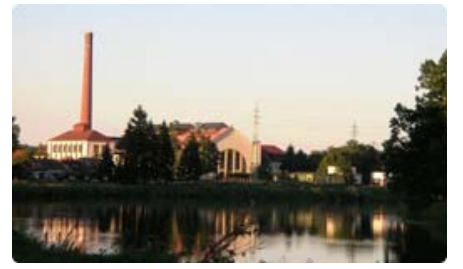

Fig. 1: The water plant in Káraný

\subsection{The Plan of Ing. Jaroslav Vancl}

In 1921, Ing. J. Vancl presented a plan to the city council. He had evaluated the development of the city, the growing number of inhabitants and the increase in the water drained from Káraný, and made a forecast for the next 70 years.

His answer to the growing needs for more water was to build dual water pipelines to Prague, and to build more water plants to collect more water.

The dual pipelines were planned to supply water of two different types. Drinkable water would be supplied from Káraný, and non-potable water would be taken from the Vltava, which could provide a sufficient amount of water for the needs of the city.

Ing. J. Vancl planned to bring $130 \mathrm{l}$ of water per day and per person into the city. Only $50 \mathrm{l}$ would be drinkable and drawn from Káraný. The rest $(80 \mathrm{l})$ would be drawn from the Vltava.

A new water plant was planned to the south of the capital, in the village of Štěchovice. A huge dam would be constructed there, according to the American model.

The main problems which prevented this plan being implemented were the enormous cost $(770$ mil. Kč to build all the dual pipelines and the dam) and the risks of bringing unclean water into the houses in Prague. Nobody could guarantee that the inhabitants would not drink this water.

\section{Podolí water supply plant}

While the city council was still assessing Vancl's plan, the situation in the Prague was slowly becoming worse and worse.

In 1923, irrespective of Vancl's plan, the city council decided to build a new water supply plant, which would supplement the water brought to the city from Káraný.

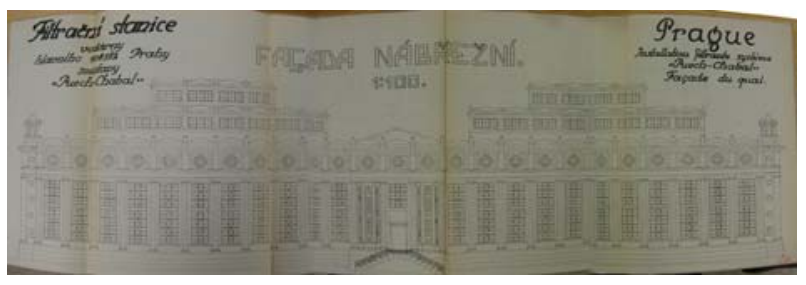

Fig. 2: The facade of the filtration building

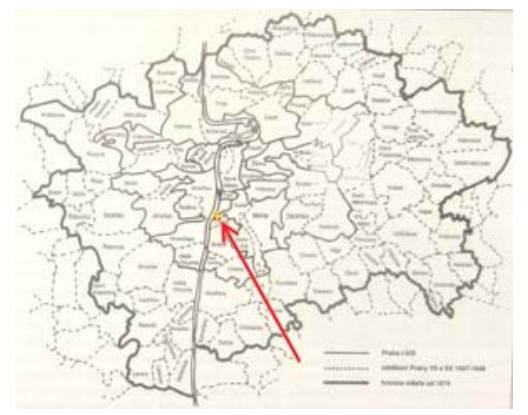

Fig. 3: Location of the water supply plant

The new plant was located in Podolí. Two water plants had been located in Podolí in the past, and the city council decided it was a suitable place for a new plant.

\subsection{Dispositions}

The two old water plants in Podolí were both founded in the 1880s. One belonged to the town of Vinohrady (a suburb with the status of a town), while the other belonged to the city of Prague.

In the early 1920 s, several tests were carried out to find the chemical composition of the underground water, which was planned to be the main source of drinkable water. Unfortunately, the underground water was found to contain too much iron and manganese, and the water was also too hard.

The solution was to use the ground water and mix it with river water. To collect ground water, the old system of collecting wells was used. They were dug on Schwarzenberg Island (now called the Rowing Island). The wells were built with an average length of $4 \mathrm{~m}$, depth $6.50 \mathrm{~m}$, and were placed $4 \mathrm{~m}$ under the surface of the island. They were connected to the water plant by a drainage pipe. All the machinery was newly rebuilt. The river water was taken through the newly built riverbed located next to the old water plant formerly belonging to Vinohrady.

Because of the moderate quality of the river water, the builders had to construct a sophisticated filtration system, which had been proposed by Vancl. It was decided to use the Puech-Chabal system, and a contract with Chabal \& Cie. was signed in 1921. This system was considered as one of the best, and the city already had good experience with it as it had been used at the Institute for the Insane at Bohnice. 


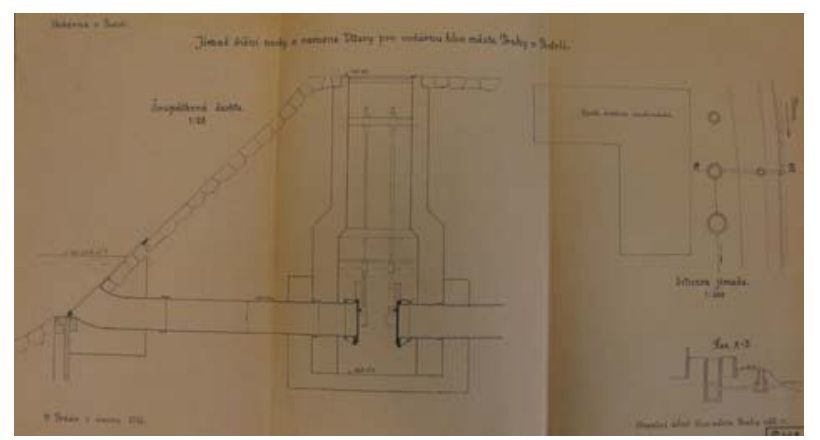

Fig. 4: Scheme for taking water from the Vltava

The filtration system was planned to have a maximum capacity of $35000 \mathrm{~m}^{3}$ of water per day.

\subsection{Construction}

In 1922, when the plans for the filtration plant had come from Chabal \& Cie., Prague also received the plans for constructing the water plant. These were just simple plans for the facade, and the whole building was a simple structure. The skeleton of the building was based on a roof structure comprising vaults with a margin of $6.50 \mathrm{~m}$, which formed twelve longitudinal fields.

As the project was developed, the original plans for the building were found to be inadequate, and a tender for the architectural design of the building was announced. The winner of the competition was Ing. Antonín Engel.

Engel proposed to build in stages, with each stage supported by a system of columns. Later, because the columns made the system too complex and too confusing, Engel changed the plans and devised a system of parabolic arches. These arches had a margin of $24 \mathrm{~m}$, and the biggest arch above the prefilters was $16 \mathrm{~m}$ in height. For this system, one huge hall $60 \times 24 \mathrm{~m}$ in size was constructed in the water plant.

The system was designed by Prof. Ing. František Klokner and Ing. Dr. Bohumil Hacar, who also made the calculations.

Further changes were made when Ing. A. Engel designed the windows and addressed the problem of sufficient sunlight. The original windows were too small, and they were replaced by squared windows over the whole area of the walls.

The building was almost completely made of concrete, and was one of the biggest concrete structures in the whole of Czechoslovakia.

The entire complex of the water plant was to consist of four buildings - two filtration plants, one engine chamber and the administrative building. In the original project, only the first filtration plant (the northern one) and the two other support buildings were constructed.

The whole complex cost Kč 17316039 .

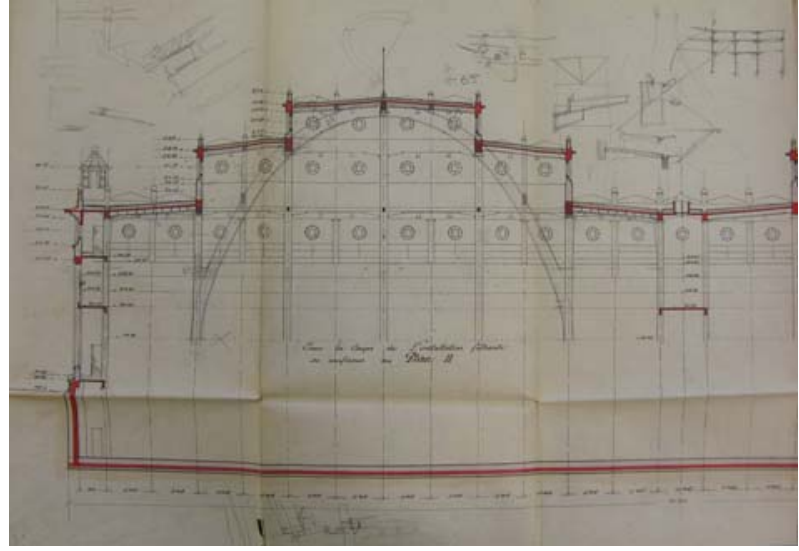

Fig. 5: The change in the architectural design of the building

\subsection{Filtration system}

The system consisted of four levels:

- large mesh filters

- prefilters

- fine filters

- tanks for clean water.

Because of a lack of space in the water plant, it was decided to stack the levels above each other, and not to place them side-by-side, as was normal in the Puech-Chabal system.

The large mesh filters and the prefilters were on the top floor, the fine filters were on the ground floor and the tanks for clean water were located in the basement.

The filters are divided into twelve parts, and the whole system is divided into two halves with an expansion joint in the longitudinal direction and also in the transverse direction.

Raw water is taken from the river and from the collecting wells through the engine building to the filtration building.

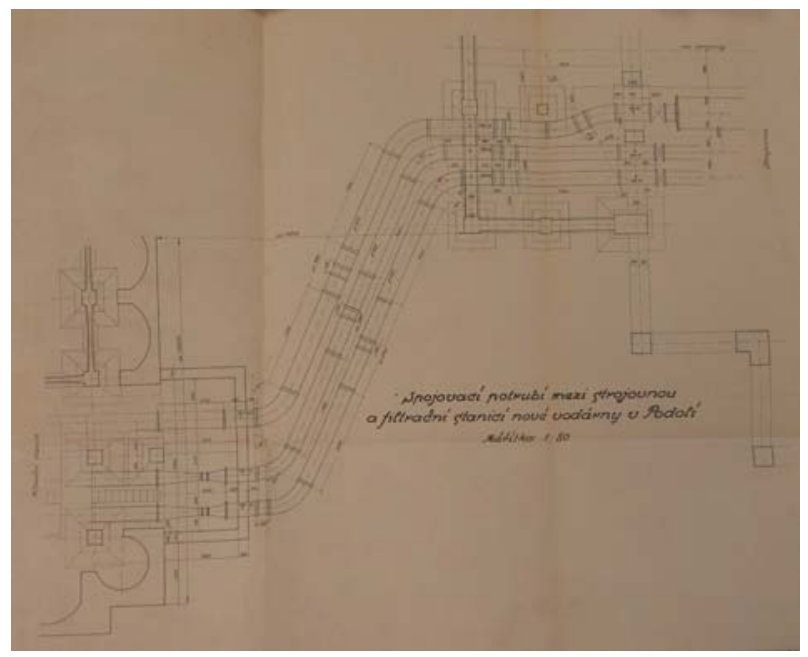

Fig. 6: Scheme of the pipelines heading from the engine building to the filtration building 


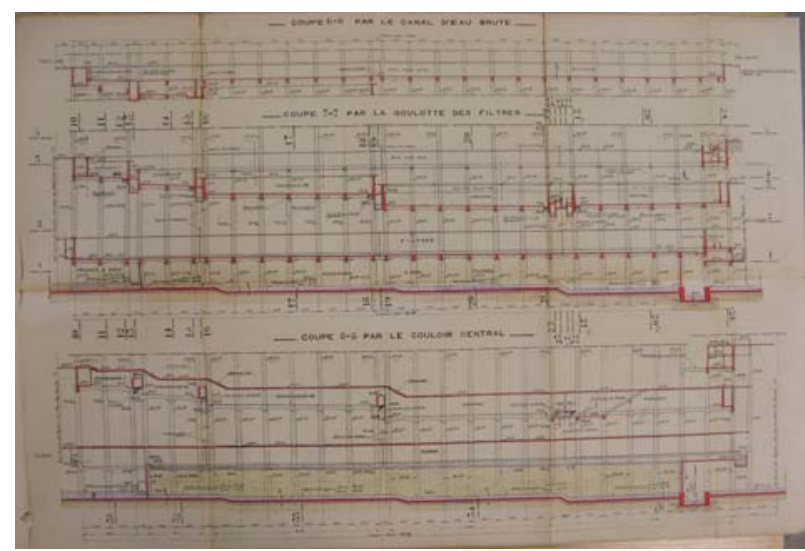

Fig. 7: Longitudinal scheme of the filters

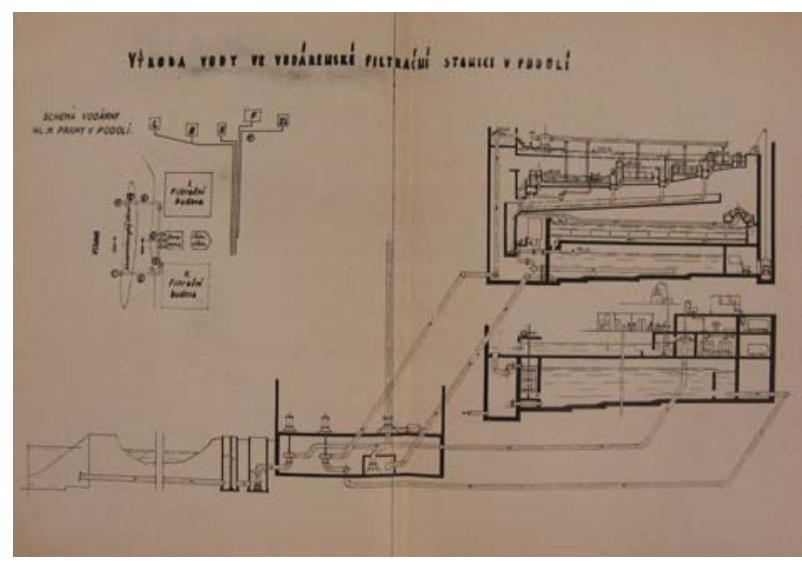

Fig. 8: Scheme of water production

\subsubsection{Filters}

The system of the filters is quite simple. Sand and gravel is put into a system of filtration beds $(54 \mathrm{~cm}$ in length and $7 \mathrm{~cm}$ in height) with 64 holes that expand conically. The water flows through the holes to the bottom of the filter and then to the small chamber that collects the water before it flows down the cascade to the next level of the filtration.

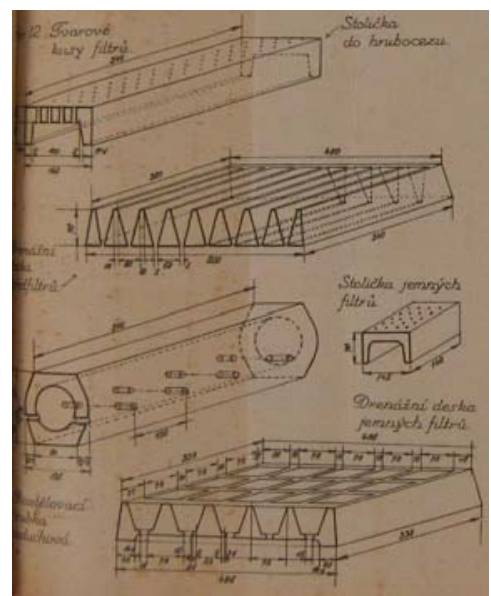

Fig. 9: Scheme of the filtration beds

\subsubsection{Large mesh filters}

The first level of filtration comprised three degrees to ensure complete removal of gross contaminants. The degrees of filtration were located above each other, like the rest of the filters.

Table 1: Parameters of the large mesh filters

\begin{tabular}{|c|c|}
\hline \multicolumn{2}{|c|}{ First degree of large mesh filters } \\
\hline Floor space & $259.30 \mathrm{~m}^{3}$ \\
\hline Height of the filter & $35 \mathrm{~cm}$ \\
\hline Grain size & $2-2.5 \mathrm{~cm}$ \\
\hline Speed of filtration & $116 \mathrm{~m}^{3} / 24 \mathrm{hrs}$ \\
\hline
\end{tabular}

\begin{tabular}{|c|c|}
\hline \multicolumn{2}{|c|}{ Second degree of large mesh filters } \\
\hline Floor space & $404 \mathrm{~m}^{3}$ \\
\hline Height of the filter & $40 \mathrm{~cm}$ \\
\hline Grain size & $1-2 \mathrm{~cm}$ \\
\hline Speed of filtration & $74 \mathrm{~m}^{3} / 24 \mathrm{hrs}$ \\
\hline
\end{tabular}

\begin{tabular}{|c|c|}
\hline \multicolumn{2}{|c|}{ Third degree of large mesh filters } \\
\hline Floor space & $1371 \mathrm{~m}^{3}$ \\
\hline Height of the filter & $50 \mathrm{~cm}$ \\
\hline Grain size & $5-10 \mathrm{~mm}$ \\
\hline Speed of filtration & $22 \mathrm{~m}^{3} / 24 \mathrm{hrs}$ \\
\hline
\end{tabular}

The first degree is supplied with unfiltered water from the doubled feeder channel, which has separated space for groundwater and for river water (the channel for the river water is enclosed, while the groundwater channel is open). At the expansion joint, the channel is connected with an iron pipeline with Gibault system expansion joints.

The water falls from the channel to the first degree from the squared hole located $7 \mathrm{~cm}$ below the water level in the channel. From the first degree, the water falls to the second degree and finally to the third degree of large mesh filters. In each degree, the water level above the gravel filter is about $75 \mathrm{~cm}$.

Each step is separated from the others by a water cascade, which helps to oxidate the water. The cascades between each degree are $30 \mathrm{~cm}$ in height, and the difference in water level between the first degree and the third degree is $2.10 \mathrm{~m}$.

The coarse sediments are removed in the large mesh filters. They are sedimented on the surface of the filters. This is the active part of the cleaning process.

\subsubsection{Prefilters}

The prefilters are also divided into six parts with an extension joint. However, due to the huge floor space 
they are also divided into two further parts. There are six prefilters on each side in two lines, with three prefilters located in each line, one behind the other.

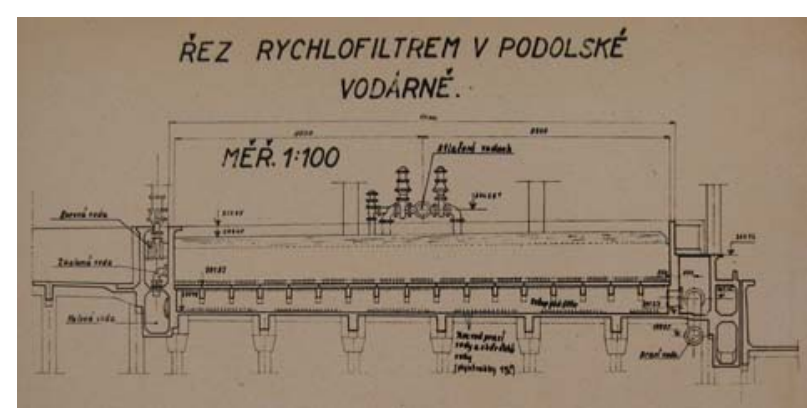

Fig. 10: Scheme of the filters

Table 2: Parameters of the prefilters

\begin{tabular}{|c|c|}
\hline \multicolumn{2}{|c|}{ Prefilters } \\
\hline Floor space & $2625 \mathrm{~m}^{3}$ \\
\hline Height of the filter & $70 \mathrm{~cm}$ \\
\hline Grain size & Up to $7 \mathrm{~mm}$ \\
\hline Speed of filtration & $11.4 \mathrm{~m}^{3} / 24 \mathrm{hrs}$ \\
\hline
\end{tabular}

The active water treatment system is the same as in the large mesh filters. The process and the filters in the prefilters are of course finer than before. The prefilters and their sand filters are also the main part of the filtration.

The membrane on the prefilters is made from fine colloidal suspensions, which are taken from the water. To accelerate the formation of the membrane, unfiltered water can also be drawn from the large mesh filters.

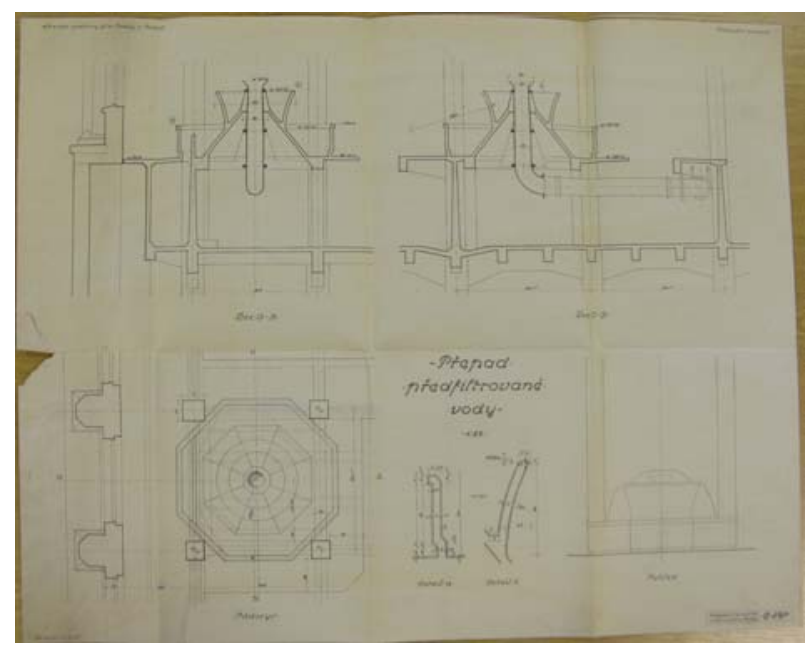

Fig. 11: Scheme of the fountains

\subsubsection{Fine filters and tanks for clean water}

The fine filters are the last level of the filtration process. They are located on the whole ground floor area and the prefiltered water is brought there by a system of fountains, making a use of the big differences in height between the prefilters and the fine filters.

Table 3: Parameters of the fine filters

\begin{tabular}{|c|c|}
\hline \multicolumn{2}{|c|}{ Fine filters } \\
\hline Floor space & $5604 \mathrm{~m}^{3}$ \\
\hline Height of the filter & $90 \mathrm{~cm}$ \\
\hline Grain size & Up to $4 \mathrm{~mm}$ \\
\hline Speed of filtration & $5.3 \mathrm{~m}^{3} / 24 \mathrm{hrs}$ \\
\hline
\end{tabular}

The fountains are an important part of the oxidation of the water. Together with the cascades between all levels of the filters, the accelerate the water cleaning process.

All twelve parts of the fine filters have their own longitudinal groove. This groove collects the final product, filtered water, and leads to the pipelines that takes the water into the collecting tanks.

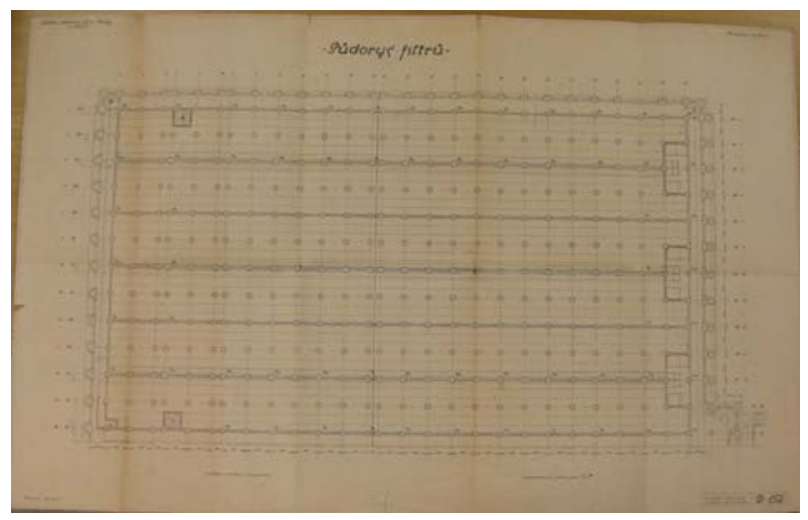

Fig. 12: Plan of the fine filters

The tanks for clean water have a capacity of $15000 \mathrm{~m}^{3}$ of water. This volume was chosen so that water will be available even if the machines taking the water to the final areas work only 16 hours a day. This was done to avoid operating the machines in the daytime, when electricity is most expensive.

The tanks are divided into four parts, and the water always flows because of the heading and suctioning pipelines, which are located $52 \mathrm{~m}$ apart.

\subsection{After completion, and the present-day situation}

The water from the Podolí water plant entered Prague's water supply system just in time. The whole project was constructed between 1923 and 1929, and in the final year the consumption of drinking water reached almost $200 \mathrm{l}$ per day and per person. The water was to undergo biological tests lasting 3-4 months, but there was no time to perform these. 
The water plant was completed in March 1929 From May the water was drawn into Prague's pipelines with water from Káraný, even though this had not been part of the plan. The plan had been to use water from the Vltava only as non-drinking water.

More recently, water from the river has been drawn into its own water tank in Flora, which was connected with the old water tank for water from Káraný. The connection for mixing those two different kinds of water was used only when that there was an inadequate stock of drinkable water.

In the 1950s, the consumption of water rose again, and even with modernization and improvements of the engines the water supply plant was not able to meet the increasing requirements. As a result, the city council decided to built on to the water plant.

Engel was again chosen as the leading architect, and he was given an opportunity to complete his project in terms of his old plans.

The building was constructed between 1957 and 1965, but from 1960 onward the unfinished water plant started to provide water for Prague's pipelines and became Prague's main source of water supply.

The water plant was in use until the great floods in 2002. Altough the water plant was not impacted by the floods thanks to Engel's good planning, it was withdrawn from the Prague system. It is now a standby water plant for use if the main water plant in Želivka is out of order.

\section{Acknowledgement}

The research presented in this paper was supervised by Prof. I. Jakubec, Faculty of Arts, Charles University in Prague and was supported by research programme No. 263101 "Man in the perspective of historical science".

\section{References}

[1] Jásek, J. \& col.: Water supply plant in Podolí and Antonín Engel. Prague 2002.

[2] Snížek, E.: The new water supply plant in Podolí and its water engineering and architectural development, The Technical Horizon - The Magazine of Czechoslovakian Engineers, 1928, vol. 36, pp. 360-440.

[3] Červenka, V.: Filtration Station in Land Institute in Bohnice. Gas and Water, 1928, vol. 8, no. 7-8, pp. 168-170.

[4] Archive of Prague's Waterworks and Sewerage (APVK), Prague Waterworks fund, panels 140-149.

\section{About the author}

Kryštof Drnek was born in Prague in 1985. He graduated from the Faculty of Arts, Charles University in Prague with a bachelor degree in 2007, and with a master degree in 2010. Since then he has been studying for a PhD degree in economic history in the Department of Economic History at the Faculty of Arts, Charles University in Prague.

Mgr. Kryštof Drnek

E-mail: drnekk@gmail.com

Dept. of Economic and Social History

Charles University in Prague

Náměstí Jana Palacha 2, 11638 Praha 1,

Czech Republic 